\section{REDIMAT}

Journal of Research in Mathematics Education

\section{Hipatia Press}

www.hipatiapress.com

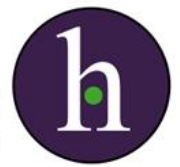

Instructions for authors, subscriptions and further details:

http://redimat.hipatiapress.com

\title{
Teams Games Tournaments (TGT) Cooperative Technique for Learning Mathematics in Secondary Schools in Bangladesh
}

Abdus Salam ${ }^{1}$, Anwar Hossain², \& Shahidur Rahman ${ }^{3}$

1) Institute of Education and Research, University of Dhaka, Bangladesh

2) Faculty of Social Science, University of Chittagong, Bangladesh

3) Interactive Computer Learning Club, University of Dhaka, Bangladesh

Date of publication: October $24^{\text {th }}, 2015$

Edition period: October 2015-February 2015

To cite this article: Salam, A., Hossain, A., \& Rahman, S. (2015). Teams games tournaments (TGT). Cooperative technique for learning mathematics in secondary schools in Bangladesh. REDIMAT, 4(3), 271-287. doi: 10.4471/redimat.2015.1519

To link this article: http://dx.doi.org/10.4471/redimat.2015.1519

PLEASE SCROLL DOWN FOR ARTICLE

The terms and conditions of use are related to the Open Journal System and to Creative Commons Attribution License (CC-BY). 


\section{Teams Games Tournaments (TGT). Cooperative Technique for Learning Mathematics in Secondary Schools in Bangladesh}

Abdus Salam

University of Dhaka

Shahidur Rahman

University of Dhaka
Anwar Hossain

University of Chittagong

(Received: 7 May 2015; Accepted: 4 October 2015; Published: 24 October 2015)

\section{Abstract}

This study investigates the effects of game playing on performance and attitudes of students towards mathematics of Grade VIII. The study was undergone by implementing TGT technique for the experimental group and typical lecture-based approach for the control group. A same achievement test was employed as in both pre-test and post-test, an inventory of attitudes towards mathematics were applied for the pre-test and post-test on TGT experimental and control group, an attitude scale on computer games was employed for the TGT experimental group, a semi-structured interview for teacher and a FGD guideline for students were applied to serving the purpose of research objectives. After three-weeks of intervention, it had been found out that TGT experimental group students had achieved a significant learning outcome than lecture based control group students. Attitude towards mathematics were differed to a certain positive extent on TGT experimental group.

Keywords: Team games tournament, cooperative learning, game playing 


\section{Torneos de Juegos de Equipo (TJE). Técnica de Cooperación para Aprender Matemáticas en Secundaria en Bangladesh}

Abdus Salam

University of Dhaka

Shahidur Rahman

University of Dhaka

\author{
Anwar Hossain \\ University of Chittagong
}

(Received: 7 May 2015; Accepted: 4 October 2015; Published: 24 October 2015)

\section{Abstract}

Este estudio investiga los efectos de los juegos sobre los resultados y las actitudes de estudiantes de matemáticas de octavo ( $4^{\circ}$ de la ESO). El estudio se realizó implementando la técnica TJE en un grupo experimental y se adoptó un enfoque típico para el grupo de control. Se utilizó el mismo test de aprendizaje tanto en el pre-test como en el post-test, así como una recopilación de actitudes hacia las matemáticas también en el pre-test y post-test en ambos grupos, y una escala de actitudes que se aplicó en el grupo TJE, además de una entrevista semi-estructurada a profesorado, y una guía FDG para estudiantes orientada a los objetivos de la investigación. Después de tres semanas de intervención, encontramos que los estudiantes del grupo experimental TJE tuvieron mejores resultados que los del grupo de control. Las actitudes hacia las matemáticas fueron más positivas hasta cierto punto, en el grupo experimental TJE.

Keywords: Torneos de juegos de equipo, aprendizaje cooperativo, uso de juegos 
$\mathbf{L}$

ow math achievement, particularly in rural secondary schools, is a significant concern in Bangladesh. A study conducted by Morshed (2013) identified from several national studies that secondary students' math performance was among the lowest of all school subjects. He further revealed that many students of secondary level even did not display sufficient competence on the basic mathematical skill that was set for primary level education in Bangladesh. However, Bangladesh government had focused on the issue and initiated a Junior School Certificate exam in 2010 where everything from course curriculum to teaching techniques, teacher's module have been revised and changed according to the international criteria. The government has emphasized most in creative questions rather than the just within-book typical set of questions.

Though the government came up with the creative question technique, some students are reaching, yet not exceeding math proficiency levels; they continue to achieve below the mathematics proficiency level. This evidence of the underachievement of secondary students is caused by several factors which may consist of improper preparation for teaching mathematics, teachers' lack of continued participation in professional development opportunities and, most importantly lack of implementation of effective instructional strategies in the mathematics classroom which do not permit students to get surfeit motivation towards solving mathematics.

It had been studying from few decades back that cooperative learning had a direct contribution to the successful learning outcome. But Wyk (2011) identified that educational practitioners are reluctant to carry this technique towards their student. While cooperative learning as an instructional methodology is an option for teachers, it is currently the least frequently applied in the classroom. Teachers could be no longer depend on direct instruction alone as a primary method of instruction by this teaching approach, the expectation that young students in secondary level education thrive in a teacher-focused, textbook-centred classroom hour-after-hour and day after day is very least naïve.

Tang et al (2009) noted that previous studies have been conducted in different settings of education, using different kinds of CL techniques. Such techniques are Learning Together (LT), Jigsaw Grouping, Teams-GamesTournaments (TGT), Group Investigation (GI), Student Teams Achievement Division (STAD), and Team Accelerated Instruction (TAI). Education For All Global Monitoring Report (2013/14) published that 
Digital classroom can enhance learning and bridge knowledge and skills gaps among less qualified teachers. It further focused on the innovation in using technology that can support improving learning by enriching teachers' curriculum delivery and encouraging flexibility in pupil learning. In this study, researchers were trying to generate a small knowledge of the literature by making students undergoing with TGT cooperative technique if they come up with effective learning outcome and the different attitude towards mathematics.

\section{Statement of the Problem}

Although the Government had thought of the necessities of ICT integration in classroom and placed a huge number of multimedia equipment in secondary institutions, there was still a stereotyped teacher-centric mathematics teaching-learning phenomenon carrying out especially in rural segment of the country. Therefore previous studies of TGT in a new setting-computer gaming for mathematics learning in rural context- should revolve a valuable contribution to recognize the effectiveness of this cooperative learning technique.

\section{Research Objectives and Hypotheses}

The study was conducted to explore the effectiveness of one of the talked of instructional technologies-TGT in secondary education of Bangladesh. The specific objectives include:

- To identify effectiveness of TGT (Teams-Games-Tournament) cooperative web-based game playing for learning mathematics.

- To ascertain the attitudinal differences of students on mathematics after TGT cooperative web-based game-playing especially in mathematics

- To recognize the effect of students' attitude towards computer game on their learning outcome.

In order to achieve the so-called objectives we set up four different hypotheses. The first one was:

$\mathrm{H}_{01}$ There is no significant difference between post-test scores of control group and experimental group. 
Our second hypothesis was:

$\mathrm{H}_{02}$ There is no significant attitude difference towards mathematics between pre-test and post-test of experimental group.

The third one was:

$\mathrm{H}_{03}$ There is no significant effect of TGT technique on both Males and Females in experimental group.

Finally, our last hypothesis was:

$\mathrm{H}_{04}$ There is no significant correlation between post-test score of experimental group and their attitude towards computer games.

\section{Methodology of the Study}

The study was basically Quasi-Experimental (pre-test and post-test) design in nature. But data was collected through mixed approach. Mainly quantitative data got the preference in conducting the study. Qualitative data was also collected as the supportive of the quantitative part and as in Triangulating data. Researchers were trying to discuss the research design, strategy, sampling, data collection method and tools, data collection and analysis procedure. Four types of tools were used to collect data according to the objectives determined previously. The tool categories are the Achievement Test, Opinion checklist, FGD Guideline, and Semi-Structured Interview Schedule.

\section{Population and Sample of the Study}

Grade eight students under secondary schools of all districts of Bangladesh is the population of the study. The preference has been given to those students, who had basic computer operational skills and had played with less-stressed games before on the computer. Mathematics teachers of secondary schools are also the population of this study. As it was a smallscale research, it was not possible for the researcher to take a sample from all over the country. Thus, the area of the study is one districts' one subdistrict / Upazila. 'Faizun-Nesa High School' has been selected as sample. In this study, the sample group is the grade eight students with basic computer operational skills and mathematics teachers. The sample group consisted of two categories, and the categories were: - Students in Grade 8 and Mathematics Teacher in Grade 8. 
Eighty-six students / participants were drawn from two intact eighthgrade classes from 'Faizun-Nesa High School'. Participants were from two sections in the same grade of eight from which 'Section $\mathrm{A}$ ' was drawn as Experimental group and 'Section B' was selected as Control group purposively. Participants from both sections were not varied by merit positions because both sections had students with same qualification level. Furthermore, participants were varied by gender $(50 \%$ Female in Experimental Group and 40\% Female in Control group).

\section{Definitions of the Terms: Teams Games Tournament}

Teams-Games-Tournaments (TGT) was originally developed by David DeVries and Keith Edwards (1972) at the Johns Hopkins University. It is one kind of cooperative learning methods. The students compete with members of other teams to contribute points to their team score. Students compete at least three-person "tournament tables" against others with a similar past record in mathematics. After then a procedure changes table assignments to keep the competition fair. The winner at each tournament table brings the same number of points to his or her team, regardless of which table it is; this means that low achievers and high achievers have an equal opportunity for success. High performing teams earn team rewards.

\section{Web-based Game Playing}

A numbers of definitions of games had been proposed. Dempsey, Haynes, Lucassen, and Casey (2002) elaborately defined: a game as a set of activities involving one or more players. It has goals, consequences, and constraints. A game is rule-guided in some aspects. Lastly, a game involves some aspect of competition, even if that competition is with oneself. Some authors investigated many definitions, and established games have particular goals and various methods of achieving these goals, which are subject to rules and constraints. Games can be played cooperatively or competitively in groups, in pairs or individually. Some complexions may increase while attempting to place any phrase or word before the word "Game" such as "Video" or "Computer" or "Web-based". The term "computer game" generally referred to a game that is played on a computer whereas "Web-based Game" generally referred to a game that is played on 
while connected to network or Internet system. In current experimental study researcher made students play Web-based Game.

\section{Concept of Cooperative Learning}

Slavin (2011) referred cooperative learning as instructional methods in which teachers organize students into small groups, and then they work together to help one another learn academic content. In cooperative learning, students work together in small groups on a structured activity. They are individually accountable for their work, and the work of the group as a whole is also assessed. Cooperative groups work face-to-face and learn to work as a team. An empirical study conducted by Whicker, Bol \& Nunnery (1997) revealed the necessity of cooperative learning for fostering mathematics education. This learning pedagogy had been vastly practiced around the whole world especially in developed countries. Improve an Israeli mathematics program that had been used through cooperative learning strategies. Studies of improve found positive effects on the mathematics achievement of elementary and middle school students in Israel (as cited in Slavin, 2011).

\section{Concept of Game Playing Integration with Learning}

There were typically assorted studies conducted on game-based learning, but very few had been found integrating Cooperative learning along with Computer games. Tang, Hanneghan and El Rhalibi (2009) defined gamesbased learning as an innovative learning approach by the usage of computer games that promote educational value or different kinds of software applications that use games for learning and education purposes and goals such as learning support, teaching enhancement, assessment and evaluation of learners. Games had demonstrated that they could provoke active user involvement through exploration, experimentation, competition and cooperation. A variety of computer games had been used in classrooms to support learning of basic arithmetic and problem-solving skills. However, the blend of collaborative gameplay with educational video games warranted investigation. A significant effect found by Ke \& Grabowski (2007) in gameplay on post-test scores and that collaborative gameplay was 
more effective than the other conditions at promoting positive attitudes towards math.

\section{Results}

\section{Students' Attitude Difference on Mathematics}

For measuring students' attitude differences towards Mathematics before and after intervention of TGT instructions, researchers tried to determine whether there was any significant difference between the means of the pretests and post-tests of the students of the experimental and control groups. A paired t-test comparing the mean scores of the pre-test and the post-test between the experimental group and control group was computed to determine if a significant difference existed.

\section{Attitude Difference on Control Group}

'Paired Samples Correlations' showed if the results found are consistent (Hington et al., 2004). Paired Sample Correlations for control group showed that none of the 16 statements under four factors of Sense of Security, Values, Motivation, Enjoyment revealed any significant differences; which was found through the significant value that not showed $\mathrm{p}<0.05$.

Table 1

Paired samples tests (control group)

\begin{tabular}{llllll}
\hline Statement & Mean & SD & t-Value & df & $\begin{array}{l}\text { Sig (2- } \\
\text { tailed) }\end{array}$ \\
\hline $\begin{array}{l}\text { I am always } \\
\text { confused in my }\end{array}$ & -.58140 & 1.65087 & -2.309 & 42 & -.026 \\
mathematics class & & & & & \\
(Factor: Sense of & & & & & \\
security, statement: & & & & \\
02 ) & & & & \\
\hline
\end{tabular}


Therefore it can be said that participants from control group are not behaving consistently as their scores on the pre-test are not significantly correlated with the post-test taken after 3-week-period, and there might be some differences in their attitudes occurred during 3-week period.

This table showed the factor or statement where the significant difference occurred between pre-test and post-test Mean scores among 16 statements. It clearly showed significant difference between Mean of pretest and post-test only on the 2 nd among 16 statements $(\mathrm{t}(42)=-2.309, \mathrm{p}<$ $0.05)$.

\section{Attitude Difference on the Experimental Group}

While conducting paired sample t-test for experimental group, it was found, like control group, that on Paired Sample Correlations none of the 16 statements revealed any significant value of $p<0.05$. Therefore it can be recognized that participants from experimental group are not behaving consistently before and after as their scores in the pre-test are not significantly correlated $(\mathrm{p}>0.05)$ with the post-test taken after 3 -weekperiod of TGT.

Table 2

Paired samples tests (experimental group)

\begin{tabular}{|c|c|c|c|c|c|c|}
\hline Serial & Statement & Mean & $\mathrm{SD}$ & $\begin{array}{c}\mathrm{t}- \\
\text { Value } \\
\end{array}$ & df & $\begin{array}{l}\text { Sig (2- } \\
\text { tailed) }\end{array}$ \\
\hline 01. & $\begin{array}{l}\text { I like any other subject } \\
\text { rather than mathematics } \\
\text { (Factor: Value, statement: } \\
\text { 02) }\end{array}$ & 2.24 & 1.56 & -8.491 & 45 & $.000 *$ \\
\hline 02. & $\begin{array}{l}\text { I want to develop my } \\
\text { mathematics skills (Factor: } \\
\text { Enjoyment, statement: 04) }\end{array}$ & -1.96 & 1.57 & 9.697 & 45 & $.000 *$ \\
\hline
\end{tabular}

$* \mathrm{p}<0.05$

Data in this table found that two pairs had significant difference in their Mean Difference. Under the factor of Value, statement 02, it was clearly evident that $\mathrm{p}<0.05$ and the column 'Mean' informed the difference 
between Mean scores of pre-test and post-test (pre-test minus post-test), and it was 2.24. Under the factor of Enjoyment, statement 04, it clearly evident a significant difference that $\mathrm{p}<0.05$. And the column-Mean informs the difference between Mean scores of pre-test and post-test (pre-test minus post-test), and it is -1.96. Therefore, Null hypothesis $\left(\mathrm{H}_{02}\right)$ has been rejected.

\section{Attitude towards Web-based Computer Games on 'Learning'}

The four statements under the factor of Learning, it was clearly visible by the Mean of 4.67 that on the first statement students were very supportive of the instructional practices they had been undergone for past 3 weeks. They were directly supporting the fact their concentration would get increased if they were used to game playing for learning purposes. Students also gave their opinion through the second statement that game playing on their relevant topic of mathematics opened the pathway to think on it. The same first statement they scored a Mean of 4.41. Nevertheless, third and fourth statements were negative opinion made for identifying data validation by the students.

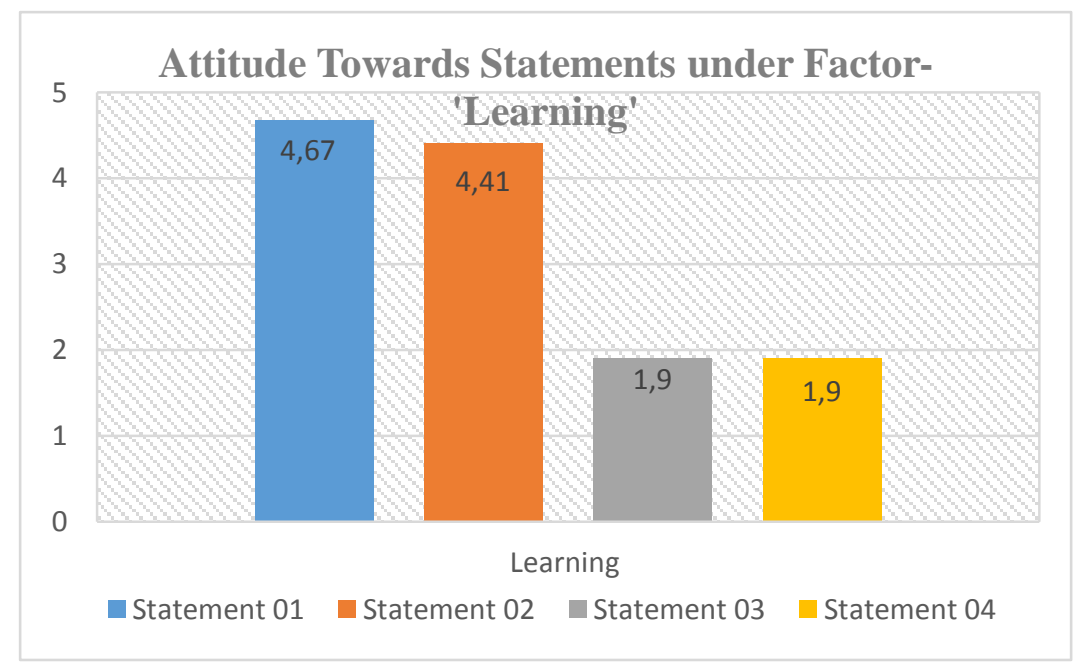

Figure 1. Attitude towards web-based computer games on learning 
Surprisingly, students disagreed (Mean of 1.90) on both statements. It indicated that, through the third and fourth statement, they wanted games as a learning tool.

\section{Effect of TGT on Students Attitude towards Web-based Computer Games}

An attitude scale towards Games as an instructional technology was put on to the students in the experimental group just after the 3-week period of TGT passed. As the scale was consisted with 5 factors (learning, confidence, liking, participation, and leisure) under 3 domains (cognitive, affection and behaviour) of attitudes with 20 statements within it, research-

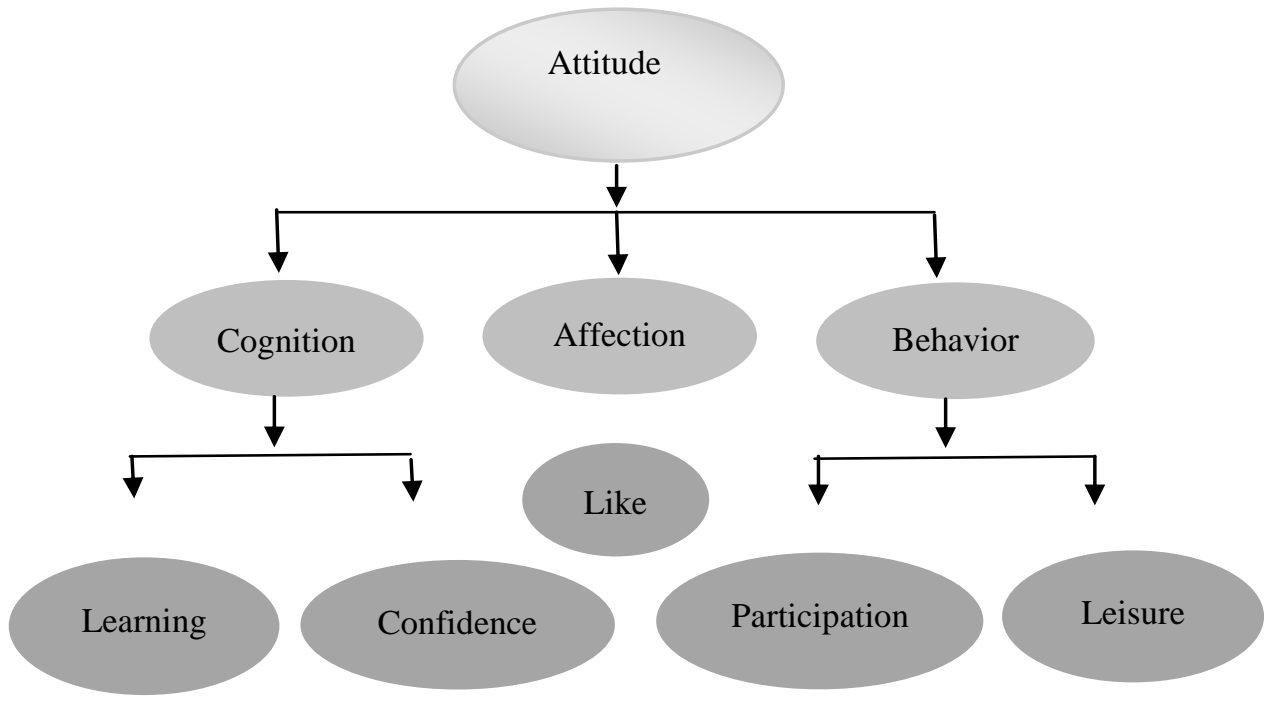

Figure 2. Focussing attitude domains towards games as instruction

ers were trying to run MANOVA (Multivariate Analysis of Variance) for identifying students' attitude towards games as an instructional tool. MANOVA revealed if there were an effect of any group i.e. gender on the combined dependent variables of attitudes. It also disclosed the relationship between dependent variables (Hington et al., 2004). In the current study, 20 statements each is a dependent variable. 
While running MANOVA, Box's test revealed the significant level: 0.058 ( $>>0.05$ ), so the result didn't violate the homogeneity of variance assumption or homogeneity of covariance assumptions. Though the pvalues was almost 0.05 , value denoted that the variables under 3 domains would be acted as same as each other.

Table 3 informed the 20 variables under 5 factors of New Computer Games Attitude Scale were not together being influenced by the TGT cooperative learning method. In the table, Wilk's Lambda test was not significant, 0.265 ( $p>0.05)$, which indicated overall on every variable there was no significant effect of TGT technique on both Male and Female. Therefore, Null hypothesis (H03) has been accepted.

Table 3

Multivariate test

\begin{tabular}{lccc}
\hline Effect & Value & F & Sig. \\
\hline Wilks' Lambda & 0.490 & 1.300 & $0.265^{* *}$ \\
\hline$* * \mathrm{p}>0.05$ & & &
\end{tabular}

Table 4 allowed looking at the homogeneity assumption for each of 20 variables (Hington, 2004). A significant result indicated that the assumption had been violated. 4 among 20 variables revealed significant $(\mathrm{p}<0.05)$ results so on these variables of Learning-01, Confidence-03, Liking-04, Leisure-02 assumption had been violated.

Table 4

Levene's test of equality of error variances

\begin{tabular}{llcc}
\hline Serial & \multicolumn{1}{c}{ Statement } & F & Sig. \\
\hline 01. & $\begin{array}{l}\text { I would be more willing to attend } \\
\text { classes if computer games were used in } \\
\text { class (Factor: Learning, statement: 01) }\end{array}$ & 14.855 & $.000^{*}$ \\
& & \\
\hline
\end{tabular}


Table $4(\ldots / \ldots)$

Levene's test of equality of error variances

\begin{tabular}{llll}
\hline 02. & $\begin{array}{l}\text { I would be happy if my test is taken } \\
\text { through computer games score (Factor: } \\
\text { Confidence, statement: 03) }\end{array}$ & 11.027 & $.002^{*}$ \\
\hline 03. & $\begin{array}{l}\text { I feel no interest on computer games } \\
\text { (Factor: Liking, statement: 04) }\end{array}$ & 6.764 & $.013^{*}$ \\
\hline 04. & $\begin{array}{l}\text { I talk about computer games with my } \\
\text { friends in my spare time (Factor: }\end{array}$ & 5.898 & $.019^{*}$ \\
& Leisure, statement: 02) & & \\
\hline$* \mathrm{p} 0.05$ & & & \\
& & & \\
\end{tabular}

\section{Students and Teachers Perception on Learning Mathematics}

A Focus Group Discussion (FGD) was conducted for helping the twelve participants among which six was from the experimental group and rest of the six was from the control group. Girls and Boys were selected in Simple Random Sampling process where the equal number (three boys and three girls from each group) of them was considered. On the other hand, a semistructured interview was conducted with mathematics teacher to getting into the perception of learning mathematic.

From the Interview schedule conducted by the mathematics teacher in grade eight, it was found that he didn't have any graduation rather he was just a degree of Higher Secondary Certificate. Nevertheless, according to him, the headmaster used to send him different training program offered by NGO and GO. Though he was got with very small number of pedagogic training, he still is following tradition approach to teaching in the classroom. When the TGT 3-weeks period was been finished, the teacher was still not motivated enough to follow them accordingly. In Interview schedule, math teacher mentioned for educational practitioners to be warned if students don't get used to only play games rather than solving them in paper-pencil format. It makes evident the critical need for sufficient training opportunities for teachers and participants. 
Mathematics Teacher showed his opinion regarding the technique game could be implied in the classroom. But it was same as the researcher before beginning of TGT method instructed him.

\section{Major Findings and Recommendations}

\section{Challenges of Teaching-Learning Practices on Mathematics}

The study school was way behind ineffective teaching-learning practices on mathematics. The researchers came up with some significant findings according to the data found from researcher's own observation, FGD by Students and Interview Schedule by the teacher.

Not having enough teachers: School had only one mathematics teacher for both sections in grade eight. He had to take classes in grade six, seven and eight. So it took much pressure on him to conduct effective mathematics classes for all the grades.

Teacher's low pedagogic profile: Mathematics teacher in grade eight had a very low pedagogic profile to conduct interactive classes to motivate students to their utmost satisfaction. The teacher was only a Higher Secondary graduate without any sufficient pedagogic training. Hence, he used to give threat to students to manage the classrooms that ultimately lead an immense chaos in the classroom. Though the school had already a graduate in mathematics with estimated training taken, but he used to take classes for upper grades i.e. grade nine \& ten. Students were also aware of their math teachers profile and wanted him to be replaced by a teacher who can make their learning integrated with technology.

Minimal ICT Infrastructure set-up: The whole school had only four laptops with only one modem that were completely insufficient for covering five classes (grade VI to $\mathrm{X}$ ) and 10 sections (two sections for each class). It may needed to make sure at least one computer with a modem in each classroom for the ideal use of ICT in regular teaching-learning phenomena.

Schools position: The school was pretty remote in geographic position and was often called on an island by the teacher. Thus, it had very low communication in terms of the vehicle, Internet and regular contacts of NGO or GO's. As the school situated at very rural area without satisfactory communication with mid-urban areas, school had very low network coverage by almost all the internet services provided in Bangladesh, thus it 
was difficult for stakeholders to be up to date with current trend of teaching-learning.

Lack of proper utilization of resources: Proper utilization of the resources was a lack in amount. The school had already been provided with 4 laptops with a modem by an NGO. Teachers had been frequently called for the various got funded training program, but they were reluctant to show the expertise they received from training into their classroom. Students were willing to learn and practice ICT skills and integrate it with their subject knowledge.

A huge number of students in a classroom: both teacher and students in grade eight that they had been quite a large number of students in each section claimed it as one of the major problems. It relatively hampers classroom management and concentration of students to learn within the classroom.

\section{Impact of TGT Techniques in the Classroom}

The main findings according to the data found from achievement test, attitude surveys of ATMI \& NCGAS by Students include the following ones:

Students Learning Outcome: Overall students from both experimental group and control group were same in their merit as the both group had similar roll numbers in the respective classroom. But when the experimental group was being undergone with TGT method they show tremendous learning outcome as expected. It clearly disclosed the effectiveness of TGT method on them. Therefore, if both groups of students were being provided with this type of Instructional technologies, there would be a chance for them to gain accordingly.

Students Attitude towards Mathematics: Students from the experimental group showed a positive attitude towards mathematics more than students from the control group. It also indicated that TGT game playing had evident some effectiveness upon them. Students in the experimental group have relatively increased their positive attitude on mathematics on all four factors of Sense of Security, Values, Motivation and Enjoyment.

Students Attitude towards Games: Students in terms of gender (Male and Female) had no significant effect of TGT technique of game playing. But apart from multivariate statistics there has been found that three 
variables under three different factors (Learning, Confidence, and Leisure) were being correlated with post-test scores of the experimental group.

\section{Recommendations}

The study was continued for total 3-weeks of period and students in experimental group performed an attitude difference very little on mathematics. But it could be suggested to undergo the treatment period for at least 4-6 weeks in different 4-6- topics to reveal more attitude difference under different factors.

It was found out no significant effect of TGT technique on both Male and Female overall on attitude towards game playing for learning purposes. Therefore, it might be suggested to put on the technique for at least 4-6 weeks to change the overall positive attitude towards game playing on both male and female.

It was quite difficult to run this type of new technique through the direction of teacher with improper pedagogic skill. Therefore, it might be recommended to recruit teachers with sufficient ICT skill as well as with pedagogic skills for taking classes.

Though it was estimated to complete each TGT cooperative method within single 40-minute class session, it wasn't possible by teacher to complete it within the time rather it took almost 60 minutes to complete whole session. So as suggested by the students, TGT technique can undertake as in after school program by which other subjects in school period would not get hampered.

Further studies should have been incorporated student training or at least a vast briefing session in working cooperatively. Researchers had observed it as a support teacher in current study that teacher overlook the fact that participants did not comprehend the dynamics of working effectively in teams. As a result, they were physically close to other participants; they worked in an individualistic manner.

Goals and expectations needed to be clearly talked and reminded every time participants are to work in groups. In addition, the teacher needed to consider if the classroom activity justified the use of cooperative learning versus individual learning. 


\section{References}

Dempsey, J. V., Haynes, L. L., Lucassen, B. A., \& Casey, M. S. (2002). Forty simple computer games and what they could mean to educators. Simulation \& Gaming, 33(2), 157-168. doi: $10.1177 / 1046878102332003$

DeVries, D. L. \& Edwards, K. J (1972). Student teams and instructional games: Their effects on cross-race and cross-sex interaction. Center for Social Organization of Schools, The Johns Hopkins University. Retrieved from: http://files.eric.ed.gov/fulltext/ED070808.pdf

Hington, P.R., Brownlow, C., Mcmurray, I. \& Cozens, B. (2004). SPSS Explained. New York, NY: Routledge.

$\mathrm{Ke}, \mathrm{F}$. (2008). Computer games application within alternative classroom goal structures: cognitive, metacognitive, and affective evaluation. Educational Technology Research and Development, 56(5), 539556. doi: 10.1007/s11423-008-9086-5

Morshed, M. M. (2013). Math anxiety and math achievement in rural junior-secondary students of Bangladesh. Proceedings from the Annual meeting of the 57th Annual Conference of the Comparative and International Education Society. New Orleans, LA.

Purwanti, D.E. (2013). The Comparison between STAD and TGT on Students, Achievement and Motivation: Senior High School. Proceedings from the Global Summit on Education. Kuala Lumpur.

Slavin, R.E. (2011). Instruction Based on Cooperative Learning. New York: Plenum.

Tang, S., Hanneghan, M., \& El Rhalibi, A. (2009). Introduction to gamesbased learning. In T. Connolly, M. Stansfield and L. Boyle (eds.), Games Based Learning Advancements for Multi-Sensory Human Computer Interfaces (pp. 1-18). New York: IGI Global.

Wyk, M. M. V. (2011). The Effects of Teams-Games-Tournaments on Achievement, Retention, and Attitudes of Economics Education Students. Journal of Social Science, 26(3), 183-193. Retrieved from: http://bit.ly/1X6722S

Whicker, K. M., Bol, L. \& Nunnery, J. A. (1997). Cooperative learning in the secondary mathematics classroom. Journal of Educational Research, 91(1) 42-48. doi: 10.1080/00220679709597519 
Abdus Salam is a Professor of Chemistry in the Faculty of Science, at the University of Dhaka, Bangladesh.

Anwar Hossain is an Assistant Professor, in the Faculty of Social Science, at the University of Chittagong, Bangladesh.

Shahidur Rahman, is a Associated Professor of Mathematics Education, in the Interactive Computer Learning Club, at the University of Dhaka, Bangladesh.

Contact Address: Direct correspondence concerning this article, should be addressed to the author. Postal address: Faculty of Social Sciences, University of Chittagong, Zobra Village, Hathajari Upajila, Chittagong-4331, Bangladesh. Email: anwaranthrocu@yahoo.com 